\title{
Ofício de Aluno / Pupilhood
}

https://doi.org/10.21814/uminho.ed.36.46

\section{Ana Cristina Palos}

Universidade dos Açores, CICS.NOVA.UAc/CICS.UAc., Portugal 



\section{Ofício de Aluno}

A expressão "ofício de aluno" surge amplamente difundida na sociologia francesa, nos anos 90 do século XX (Sirota, 1993; Perrenoud, 1994), para designar a integração das crianças e dos jovens na cultura e no modelo de socialização proposto pela escola.

Este modelo de socialização escolar mantém ainda hoje, e apesar das inúmeras experiências de inovação pedagógica e das singularidades nacionais, um conjunto de invariantes estruturais que se consolidaram e difundiram a nível mundial com a construção da escola pública, no século XIX.

Entre essas invariantes estruturais que permitem caracterizar o ofício de aluno, destaca-se uma relação específica com o saber. Uma das características que tem sido mais evidenciada na caracterização do modelo escolar consiste no facto de este privilegiar os saberes abstratos e descontextualizados, subvalorizando as competências práticas e sobrevalorizando os conhecimentos teóricos, condição que justifica a desvalorização que a escola manifesta relativamente aos saberes, experiências e interesses específicos dos alunos que integra.

Também as formas de organização do trabalho pedagógico constituem um dos traços culturais da forma escolar. Aqui, os processos educativos parecem construídos mais em função de quem ensina e menos em função de quem aprende. Tal verifica-se a nível da construção do próprio currículo, concebido enquanto um plano de ensino construído e estruturado pelo professor e onde o trabalho curricular se desenvolve em função dos objetivos e conteúdos prescritos, independentemente da experiência pessoal dos alunos. A organização dos espaços e dos tempos de aprendizagem também denuncia a normalização de práticas educativas, verificando-se que, independentemente do contexto escolar, se pratica uma pedagogia centrada essencialmente na sala de aula, com tempos e horários de ação escolar rigidamente estruturados, sendo mobilizadas formas de avaliação direcionadas, basicamente, para a reprodução de conhecimentos memorizados.

A qualidade da relação pedagógica é outra das características que corporizam a imagem que culturalmente se impõe quando falamos de ensino. 
A matriz organizacional da escola que temos vindo a referir reserva ao professor um papel essencialmente de transmissor de conhecimentos, consumidos mais ou menos passivamente pelos alunos. Trata-se de uma relação de poder assimétrica em que se pressupõe a autoridade do professor, o seu poder de controlo sobre a classe e a possibilidade de sancionar os comportamentos dos alunos em função de regras impessoais, definidas de forma exclusiva pelos adultos.

O modelo escolar caracteriza-se ainda por preconizar uma separação entre a atividade escolar e as outras práticas sociais. Na generalidade dos contextos de educação não formais - família e grupo de pares, por exemplo - a aprendizagem dos mais novos decorre com naturalidade e espontaneidade, sendo valorizados os saberes práticos e a aprendizagem pela experiência. De forma inversa, a escola promove, precocemente, uma separação com os outros contextos para os quais é suposto preparar os alunos, isolando-os, de forma literal e simbólica, das práticas sociais que aí ocorrem.

Mas, no contexto das sociedades atuais, o uso das tecnologias de informação e comunicação (TIC) coloniza o quotidiano das crianças e dos jovens e o seu impacto no processo de aprendizagem pode configurar uma verdadeira "reinvenção do ofício de aluno" (Sarmento, 2011). Consideramos que, e contrariamente às expectativas iniciais, a introdução das novas tecnologias nas escolas ainda não alterou substancialmente a lógica escolar, dado que, na generalidade das escolas portuguesas, o que transparece é que, ao invés de transformarem o núcleo duro do modelo escolar, as TIC, frequentemente, acomodaram-se a essa lógica assumindo a forma de mais um conteúdo escolar.

Mas ainda que o "programa institucional" possa não ter sofrido modificações profundas em função da disseminação das TIC nos contextos escolares, e que a sua utilização não garanta a modificação da relação pedagógica, não podemos escamotear que a sua utilização generalizada tem como consequência imediata a ampliação dos recursos e das ferramentas que permitem aos alunos acederem ao conhecimento, condição que fragiliza o monopólio da escola enquanto universo, por excelência, de acesso ao saber e introduz uma nova dimensão no ofício de aluno, designada por Sarmento (2011) de e-ofício, entendido como o "o desempenho, pelas crianças, das suas actividades de aprendizagem enquanto utilizadores activos das tecnologias de informação e comunicação" (p. 394). 
Neste contexto, a relação pedagógica parece reconfigurar-se, na medida em que as crianças e os jovens são mais competentes do que os adultos na descodificação e no reconhecimento das potencialidades instrumentais das tecnologias. Esta questão, aliada à progressiva consagração dos direitos dos mais novos no contexto das sociedades democráticas, está a conduzir a profundas alterações nas representações sociais sobre a infância e a juventude que tendem a acentuar o reconhecimento da individualidade e da autonomia do aluno, a sua "alteridade cultural face aos adultos" (Sarmento, 2011, p. 599).

Neste contexto, criam-se as condições para que se acentue o pensamento crítico sobre o modelo escolar e ganhem cada vez mais sentido as propostas pedagógicas que, desde o século XIX, reconhecem ao aluno um papel central e ativo nos processos de aprendizagem e proclamam uma ação pedagógica ajustada às suas necessidades e interesses.

\section{Pupilhood}

The expression "Métier d'élève" or pupilhood was widely used in French sociology, in the 1990s (Sirota, 1993; Perrenoud, 1994), to designate the integration of children and young people into the culture and socialization model proposed by school. This model still dominates today, and despite the countless experiences of pedagogical innovation and national singularities, a set of structural invariants that were consolidated and disseminated worldwide with the construction of the public school in the 19th century, prevails.

Among these structural invariants that allow the definition of pupilhood, a specific relationship with knowledge stands out. One of the characteristics that has been most evident in the defining of the school model is the fact that it favours abstract and decontextualized knowledge, underestimating practical skills and overestimating theoretical knowledge. This is a condition that explains the school's devaluing of knowledge, experiences and the specific interests of the students.

The forms of organization of pedagogical work are also some of the cultural features of the school model. Here, the educational processes seem to be more based on those who teach and less on those who learn. This is verified in terms of the construction of the curriculum itself, conceived as a teaching plan built and structured by the teacher. Here the curricular work is developed according to the objectives and prescribed contents, regardless 
of the students' personal experience. The organization of learning spaces and times also prevents the normalization of educational practices, verifying that, regardless of the school context, pedagogy is practised essentially in the classroom, with rigidly structured school timetables and schedules, while the evaluation approaches value the reproduction of memorized knowledge.

The quality of the pedagogical relationship is another characteristic that embodies the image that is culturally imposed when we think of teaching. The school's organizational model, to which we have been referring, regards the teacher essentially as a transmitter of knowledge that is consumed, more or less passively, by the students. It is an asymmetrical power relationship that presupposes the teacher's authority, his power of control over the class and the possibility of sanctioning students' behavior according to impersonal rules, defined exclusively by adults.

The school model is also characterized by advocating a separation between school activity and other social practices. In most non-formal educational contexts - family and peer group, for example - the learning of the young takes place naturally and spontaneously, practical knowledge and learning through experience being valued. On the contrary, the school promotes, from an early stage, a separation from the other contexts for which it is supposed to prepare students, isolating them, literally and symbolically, from the social practices that occur there.

However, in the context of contemporary societies, the use of information and communication technologies (ICT) colonizes the daily lives of children and young people and their impact on the learning process could constitute a true "reinvention of pupilhood" (Sarmento, 2011). We consider that, contrary to initial expectations, the introduction of new technologies in schools has not yet substantially changed the school model in most Portuguese schools. What appears is that, instead of transforming the hard core of the school model, ICT has often been subsumed by this system so that it takes the form of yet another school subject. But even though the "institutional program" may not have undergone profound changes due to the spread of ICT in school contexts, and that its use does not guarantee the modification of the pedagogical relationship, we must acknowledge that its widespread use has the immediate consequence of expansion of resources and tools that allow students to access knowledge. This is a condition that weakens the school monopoly as a universe, par excellence, of access to knowledge and introduces a new dimension in student craft, designated by 
Sarmento (2011) the e-craft, understood as "children's performance of their learning activities as active users of information and communication technologies" (p. 394).

In this context, the pedagogical relationship seems to be reconfigured, as children and young people are more competent than adults in decoding and recognizing the instrumental potential of technologies. This situation, coupled with the progressive acceptance of the rights of the youngest in the context of democratic societies, is leading to profound changes in social representations about childhood and youth that tend to accentuate the recognition of the student's individuality and autonomy, his "cultural alterity in relation with adults" (Sarmento, 2011, p. 599).

In this context, not only the critical thinking about the school model gains legitimacy, but also the pedagogical proposals that, after the 19th century, recognize that students have a central and active role in the learning processes and advocate an approach adjusted to their needs and interests.

\section{Referências / References}

Perrenoud, P. (1994). Métier d'élève et sens du travail scolaire. Paris: ESF.

Sarmento, M. J. (2011). A reinvenção do ofício de criança e aluno. Atos de Pesquisa em Educação, 6 (3), 581-602.

Sirota, R. (1993). Le métier d'élève. Revue Française de Pédagogie, 104, (1), 85-108. 